\title{
Komitmen Kerja, Lingkungan Kerja Nonfisik, dan Work Interference With Family terhadap Kinerja Pegawai pada Badan Kepegawaian dan Pengembangan Sumber Daya Manusia
}

\author{
I Made Adi Suwandana1, Ni Ketut Sari Pebriyanthi ${ }^{2}$ \\ 1,2 Fakultas of Ekonomi dan Bisnis, Universitas Ngurah Rai Denpasar, Denpasar, Indonesia
}

\section{Keywords:}

Commitment;

Environment;

Work Interferece

With Family and

Employee

Performance
Kata kunci:

Komitmen;

Lingkungan;

Work Interferece

with Family dan

Kinerja Pegawai

\section{ABSTRACT}

Abstract: Many employees still keep their distance and compare each other so that the work environment is not harmonious, sometimes employees keep their distance from their superiors because they are afraid of their boss's harsh leadership style and communication between subordinates and superiors is not good. The purpose of this study was to analyze the effect of partially or simultaneously Work Commitment, Non-Physical Work Environment and Work Interferece with Family on Employee Performance at the Agency for Personnel and Human Resources Development. The research model used is quantitative research methods. The population in this study amounted to 68 people. The sampling technique is probability sampling with 67 respondents. Data were analyzed using classical assumption test, multiple linear regression analysis, analysis of determination, simultaneous significance test ( $F$-test) and partial significance test (t-test). The results showed that the $f$-count value was $5.682>$ from the $f$-table value of 1.518 and the $f$-count with a significant value of 0.002 which indicated that the variables of Work Commitment, Non-Physical Work Environment and Work Interference with Family had a positive and significant effect on employee performance at the Civil Service Agency. Human Resource Development. The implications of this research can provide an evaluation in improving employee performance.

Abstrak: Banyak pegawai yang masih menjaga jarak dan membanding-bandingkan satu sama lain, sehingga lingkungan kerja menjadi tidak terjalin dengan harmonis. Terkadang pegawai menjaga jarak dengan atasannya karena merasa takut dengan gaya kepemimpinan atasannya yang keras dan komunikasi bawahan dengan atasan tidak terjalin baik. Tujuan penelitian ini adalah untuk menganalisis pengaruh secara parsial atau simultan komitmen kerja, lingkungan kerja nonfisik dan work nterferece with family terhadap kinerja pegawai pada Badan Kepegawaian dan Pengembangan Sumber Daya Manusia. Model penelitian yang digunakan adalah metode penelitian kuantitatif. Populasi dalam penelitian ini berjumlah 68 orang. Teknik sampling adalah probability sampling dengan sebanyak 67 orang responden. Data dianalisis dengan menggunakan uji asumsi klasik, analisis regresi linier berganda, analisis determinasi, uji signifikansi simultan (F-test) dan uji signifikansi parsial (t-test). Hasil penelitian menunjukkan nilai $f_{\text {-hitung }} 5,682>$ dari nilai $f_{\text {-tabel }} 1,518$ dan $f_{\text {-hitung }}$ dengan nilai signifikansi 0,002 yang

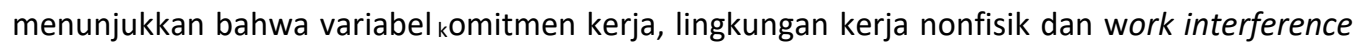
with family berpengaruh positif dan signifikan terhadap kinerja pegawai pada Badan Kepegawaian Dan Pengembangan Sumber Daya Manusia. Implikasi penelitian ini dapat memberikan evaluasi dalam meningkatkan kinerja karyawan.

\footnotetext{
Alamat Korespondensi:

E-mail: suwandana@unr.ac.id (Suwandana)
}

\section{Pendahuluan}

Pada dasarnya kinerja karyawan merupakan cara kerja karyawan dalam suatu perusahaan selama periode tertentu (Effendi \& Yogie, 2019; Farhah et al., 2020; Rachmawati, 2017). Suatu perusahaan yang memiliki karyawan dengan kinerjanya baik, maka besar kemungkinan kinerja

$\begin{array}{ll}\text { History: } & \\ \text { Received } & \text { :08 Mei } 2021 \\ \text { Revised } & \text { : 09 Mei } 2021 \\ \text { Accepted } & \text { : 16 Juni } 2021 \\ \text { Published } & \text { : 25 April } 2021\end{array}$

\section{History:}

Received

Published
Publisher: Undiksha Press

Licensed: This work is licensed under a Creative Commons Attribution 3.0 License

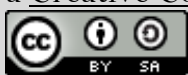


perusahaan tersebut juga baik, sehingga terdapat hubungan yang sangat erat antara kinerja individu (karyawan) dan kinerja perusahaan (Aini Kusniawati, 2019; Jufrizen, 2017). Salah satu indikator utama dalam pencapaian SDM yang unggul dan berdaya saing global adalah kinerja SDM/aparatur. Pemerintah daerah dituntut untuk melaksanakan program prioritas pusat dalam pembinaan dan pembentukan karakter SDM, yang dikoodinasikan langsung oleh Bapak Presiden Republik Indonesia, diawasi oleh Kementerian Pendayagunaan Aparatur Negara Reformasi Birokrasi, dan Badan Kepegawaian Negara. Pemerintah daerah juga mempunyai instansi yaitu Badan Kepegawaian dan Pengembangan Sumber Daya Manusia, yang mempunyai tugas memimpin, mengoordinasikan fungsi penunjang urusan pemerintahan yang menjadi kewenangan daerah di bidang kepegawaian, pendidikan, dan pelatihan (Mustopa, 2020).

Pemerintah Kabupaten Gianyar, dalam hal ini Badan Kepegawaian dan Pengembangan Sumber Daya Manusia Kabupaten Gianyar adalah suatu instansi yang bergerak dalam bidang kepegawaian. Tugas utama Badan Kepegawaian dan Pengembangan Sumber Daya Manusia yaitu berkaitan dengan pengelolaan SDM, mulai dari rekrutmen aparatur, seleksi, penempatan, pelatihan (diklat), mutasi, penentuan masa kerja (pensiun), dan disiplin pegawai. Berdasarkan hasil wawancara, beberapa staf tidak mengetahui secara jelas tujuan dan nilai-nilai organisasi, serta masih banyak pegawai yang tidak mencerminkan rasa kekeluargaan dalam instansi tersebut. Banyak pegawai yang masih menjaga jarak dan membanding-bandingkan satu sama lain, sehingga lingkungan kerja menjadi tidak terjalin dengan harmonis, terkadang pegawai menjaga jarak dengan atasannya karena merasa takut dengan gaya kepemimpinan atasannya yang keras dan komunikasi bawahan dengan atasan tidak terjalin baik.

Pimpinan juga kurang memberikan reward kepada pegawai yang memiliki prestasi kerja yang baik. Pegawai malas untuk bekerja karena kurang diperhatikan oleh atasannya dan hubungan antarekan kerja kurang harmonis, pekerjaan tidak selesai dengan tepat waktu, seperti banyak SPJ-SPJ yang harusnya sudah diamprah pada triwulan yang sudah ditentukan, namun tertunda dan tidak berjalan sesuai dengan waktunya, banyak pegawai yang tidak disiplin, dan lainnya. Pemahaman tentang peraturan-peraturan ke dalam diri pegawai yang kemudian membentuk kesadaran untuk memahaminya juga belum maksimal. Pemahaman mengenai hubungan komitmen kerja, lingkungan kerja nonfisik, work intefarance with family terhadap kinerja pegawai menjadi sesuatu kurang dipahami dan diterapkan oleh para pejabat dan staf Badan Kepegawaian dan Pengembangan Sumber Daya Manusia Kabupaten Gianyar.

Komitmen menjadi salah satu hal yang dianggap berpengaruh terhadap kinerja pegawai meskipun kompensasi diberikan begitu besar kepada pegawai belum tentu itu dapat menjamin meningkatnya komitmen pegawai dalam kinerjanya (Lestri, 2020; Wibowo, 2017). Komitmen berasal dari dalam diri seseorang itu sendiri yang mau bertahan di suatu instansi tersebut tanpa harus meminta kompenasi yang lebih. Komitmen berasal dari bahasa Latin commitere, to connect, entrustthe state of being obligated or emotionally, impelled adalah keyakinan yang mengiat (aqad) sedemikian kukuhnya, sehingga membelenggu seluruh hati nuraninya dan kemudian menggerakan perilaku menuju arah yang diyakini. Komitmen sebagai salah satu keadaan yang menuntut seorang karyawan memihak pada satu organisasi tertentu dan tujuan-tujuannya serta berniat memelihara keanggotaan dalam organisasi tersebut (Lengkong, 2018; Lestri, 2020).

Lingkungan kerja terbagi menjadi dua yaitu lingkungan kerja fisik berupa aset fisik yang dimiliki perusahaan dan lingkungan kerja nonfisik yang merupakan bagian dari lingkungan kerja keseluruhan yang di dalamnya mencangkup perilaku orang-orang yang berada dalam organisasi (Nabawi, 2019; Noorainy, 2017). Apabila lingkungan kerja fisik mendukung, maka karyawan dalam melaksanakan tugas dan tanggung jawabnya akan meningkat, karyawan bisa memberikan kinerja yang baik, dan dapat menyelesiakan pekerjaan tepat waktu (Noorainy, 2017; Suryani, 2019). Selain itu, Work Interferance With Family adalah konflik yang terjadi ketika aktivitas pekerjaan menganggu tanggung jawab individu dalam lingkungan keluarga (Annisa \& Amallia, 2021; Filatrovi et al., 2021). Pemenuhan peran dalam pekerjaan dapat menimbulkan kesulitan pemenuhan peran dalam keluarga dan berpengaruh kinerja pegawai. Suatu lingkungan pekerjaan, khususnya di instansi pemerintahan, sangat diperlukan hubungan antara komitmen kerja, lingkungan kerja nonfisik, dan work interferance 
with family, sehingga berpengaruh terhadap kinerja masing-masing instansi, seperti yang tercantum dalam tujuan utama dari pemerintah pusat saat ini yaitu pembangunan sumber daya manusia yang unggul dan berdaya saing global dapat tercapai (Annisa \& Amallia, 2021; Hekayanti \& Yulianti, 2021).

Penelitian ini sejalan dengan penelitian sebelumnya yang menyatakan komitmen memberikan pengaruh terhadap kinerja karyawan, komitmen yang tinggi akan menyebabkan kinerja tinggi juga (Lengkong, 2018; Lestri, 2020; Wibowo, 2017). Penelitian sebelumnya menyatakan lingkungan juga berperan dalam meningkatkan kinerja karyawan, baik lingkungan fisik maupun nonfisik (Nabawi, 2019; Noorainy, 2017; Suryani, 2019). Selanjutnya, penelitian yang menyatakan bahwa work interference with family berpengaruh negatif terhadap kinerja pegawai (Annisa \& Amallia, 2021; Hariyadi, 2018; Hekayanti \& Yulianti, 2021). Tujuan penelitian ini untuk menganalisis pengaruh komitmen kerja, lingkungan kerja nonfisik, dan work interference with family secara simultan terhadap kinerja pegawai.

\section{Metode}

Model penelitian yang digunakan adalah metode penelitian kuantitatif. Metode kuantitatif adalah metode penelitian yang menggunakan proses data-data yang berupa angka sebagai alat menganalisis dan melakukan kajian penelitian, terutama mengenal apa yang sudah diteliti. Populasi dalam penelitian ini adalah seluruh pegawai di lingkungan Badan Kepegawaian Dan Pengembangan Sumber Daya Manusia Kabupaten Gianyar yang berjumlah 68 orang. Cara pengambilan sampel atau teknik sampling dalam penelitian ini adalah dengan cara probability sampling. Probability sampling adalah teknik pengambilan sampel yang memberikan peluang yang sama bagi setiap unsur (anggota) populasi dipilih untuk menjadi anggota sampel. Jumlah populasi yang ada pada Badan Kepegawaian dan Pengembangan Sumber Daya Manusia yaitu sebanyak 67 orang responden. Teknik pengumpulan data menggunakan, observasi, wawancara langsung, studi dokumentasi, angket (kuesioner).

Kuesioner adalah teknik pengumpulan data yang dilakukan dengan cara memberi seperangkat pertanyaan atau pernyataan tertulis kepada responden untuk dijawab (Sugiono, 2018). Kuesioner ini diberikan kepada semua yang menjadi responden pada Badan Kepegawaian Dan Pengembangan Sumber Daya Manusia Kabupaten Gianyar. Penelitian ini menggunakan kuesioner tertutup. Kuesioner tertutup adalah kuesioner yang telah menyediakan pilihan jawaban untuk dipilih oleh objek penelitian. Pada bagian ini juga disajikan skala pengukuran instrumen penelitian. Ada beberapa skala pengukuran instrumen penelitian yang digunakan dalam pembuatan kuesioner, tapi penelitian ini memilih menggunakan pengukuran Skala Likert berikut pengertiannya.

Setiap jawaban kuesioner mempunyai bobot atau skor nilai dengan skala Likert ini adalah dari skor 5 sampai dengan 1. Bentuk jawaban skala Likert terdiri dari sangat setuju, setuju, netral, tidak setuju, dan sangat tidak setuju. Teknik analisis data dalam penelitian ini menggunakan pendekatan kuantitatif yaitu terdiri dari: uji asumsi klasik, analisis regresi linier berganda, analisis determinasi, analisis statistik uji $\mathrm{F}\left(\mathrm{F}_{\text {-test }}\right)$ dan Analisis Statistik Uji $\mathrm{t}(\mathrm{t}$-test).

\section{Hasil dan Pembahasan}

\section{Hasil Penelitian}

Pada penelitian yang dilakukan pada Badan Kepegawaian dan Pengembangan Sumber Daya Manusia Kabupaten Gianyar, uji asumsi klasik digunakan untuk mengetahui kelayakan penggunaan model regresi. Hasil uji multikolinearitas dapat dilihat pada Tabel 1.

Tabel 1. Hasil Uji Multikolinearitas

\begin{tabular}{lcc}
\hline \multicolumn{1}{c}{ Variabel Bebas } & \multicolumn{2}{c}{ Collinearity Statistic } \\
\cline { 2 - 3 } & Tolerance & VIF \\
\hline Komitmen Kerja $\left(\mathrm{X}_{1}\right)$ & 0,898 & 1,113 \\
Lingk. Kerja Non Fisik $\left(\mathrm{X}_{2}\right)$ & 0,915 & 1,092 \\
Work interference with family $\left(\mathrm{X}_{3}\right)$ & 0,994 & 1,059 \\
\hline
\end{tabular}


Berdasarkan Tabel 1 dapat disimpulkan bahwa model regresi layak dipakai dalam penelitian ini karena syarat untuk tidak terjadi multikolonieritas sudah dipenuhiyakni nilai tolerance $>0,10$ atau sama dengan nilai VIF $<10$. Selanjutnya dilakukan uji keteroskedastisitas. Hasil uji heteroskedastisitas dapat dilihat pada Tabel 2.

Tabel 2. Hasil Uji Heteroskedastisitas

\begin{tabular}{lc}
\hline \multicolumn{1}{c}{ Variabel Bebas } & Sig \\
\hline Komitmen Kerja & 0,085 \\
Lingkungan Kerja Non Fisik & 0,060 \\
Work interference with family & 0,917 \\
\hline
\end{tabular}

Berdasarkan tampilan pada scatterplot pada Tabel 2 di atas terlihat pada model regresi yang terbentuk dinyatakan tidak terjadi gejala heteroskedastisitas. Hasil uji normalitas dapat dilihat pada Tabel 3.

Tabel 3. Hasil Uji Normalitas dengan Uji Kolmogorov-Smirnov

\begin{tabular}{lc}
\hline & Unstandardized Residual \\
\hline $\mathrm{N}$ & 67 \\
Kolmogorov-Smirnov Z & 0,090 \\
Aymp. Sig (2 -tailed) & 0,200 \\
\hline
\end{tabular}

Berdasarkan hasil uji normalitas pada data di atas, diketahui bahwa nilai Asymp. Sig. (2tailed) adalah 0,200 alpha $=0,05$. Dengan demikian nilai residual berdistribusi normal.

Tabel 4. Rekapitulasi Hasil Analisis Regresi Linier Berganda

\begin{tabular}{lcc}
\hline \multicolumn{1}{c}{ Variabel } & B & Sig \\
\hline Konstanta & $10,9670,488$ & 0,000 \\
Komitmen Kerja & 0.166 & 0,001 \\
Lingkungan Kerja Non Fisik & $-0,050$ & 0,340 \\
Work interference with family & & 0,581 \\
\hline
\end{tabular}

Berdasarkan Tabel 4 diperoleh persamaan regresi linier berganda adalah: $Y=10,967+0,488$ $X_{1}+0,166 X_{2}+-0,050 X_{3}$, sehingga memberikan informasi bahwa $a=10,967$ artinuya apabila tidak ada perubahan pada variabel komitmen kerja, lingkungan kerja nonfisik dan work interference with family atau nilainya adalah konstan, maka skor kinerja adalah 10,967 satuan. $b_{1}=0,488$ artinya apabila variabel lain dianggap konstan maka menunjukkan skor komitmen kerja sebesar 11,455 satuan maka akan diikuti oleh meningkatnya skor kinerja pegawai sebesar 0,488 satuan. $b_{2}=0,166$ artinya apabila variabel lain dianggap konstan maka menunjukan skor lingkungan kerja nonfisik sebesar 11,133 satuan maka akan diikuti oleh meningkatnya skor kinerja pegawai sebesar 0,166 satuan. $b_{3}=0,050$ artinya artinya apabila variabel lain dianggap tidak konstan maka menunjukan skor work interference with family sebesar -11,017 satuan maka akan diikuti oleh menurunnya skor kinerja pegawai sebesar 0,050 satuan.

Hasil analisis determinasi diperoleh koefisien determinasi ( $R$ Square) adalah 0,213. Menunjukan bahwa perubahan komitmen kerja, lingkungan kerja nonfisik dan work interference with family terhadap perubahan kinerja pergawai pada Badan Kepegawaian dan Pengembangan Sumber Daya Manusia Kabupaten Gianyar sebesar $21,30 \%$ sedangkan sisanya sebesar $78,70 \%$ dijelaskan variabel lain yang tidak dibahas dalam penelitian ini. Hasil uji hipotesis menggunakan uji statistik $F(F$. test) menunjukkan bahwa nilai $f_{\text {-hitung }} 5.682>$ dari nilai $f_{\text {-tabel }} 1,518$ dan $f_{\text {-hitung }}$ berada pada daerah penolakan $\mathrm{H}_{0}$. Oleh karena itu, $\mathrm{H}_{0}$ ditolah dan $\mathrm{H}_{a}$ diterima. Dapat disimpulkan bahwa komitmen kerja, 
lingkungan kerja nonfisik dan work interference with family berpengaruh positif dan signifikan secara simultan terhadap kinerja pegawai. Hasil uji hipotesis menggunakan uji statistik $t\left(t_{\text {-test }}\right)$ dapat dilihat pada Tabel 5.

Tabel 5. Hasil Uji Signifikansi Parsial ( $\left.\mathrm{t}_{\text {-test }}\right)$

\begin{tabular}{lcc}
\hline \multicolumn{1}{c}{ Model } & t & Sig. $\mathbf{~}$ \\
\hline Konstanta & - & - \\
Komitmen Kerja $\left(\mathrm{X}_{1}\right)$ & 3,605 & 0,001 \\
Lingk. Kerja Non Fisik $\left(\mathrm{X}_{2}\right)$ & 0,691 & 0,340 \\
Work interference with family $\left(\mathrm{X}_{3}\right)$ & $-0,555$ & 0,581 \\
\hline
\end{tabular}

Berdasarkan Tabel 5 dapat diketahui bahwa nilai $t_{1-\text { hitung }}=3,605>$ dari nilai $\mathrm{t}_{\text {-tabel }} 1,998$, dan $\mathrm{t}$ hitung berada pada daerah penolakan $\mathrm{H}_{0}$, oleh karena itu $\mathrm{H}_{0}$ ditolak dan $\mathrm{H}_{\mathrm{a}}$ diterima. Maka komitmen kerja secara parsial mempunyai pengaruh yang positif dan signifikan terhadap kinerja pegawai. Nilai $\mathrm{t}_{2 \text {-hitung }}=0,691<$ dari nilai $\mathrm{t}_{\text {-tabel }} 1,998$, dan $\mathrm{t}$-hitung berada pada daerah penolakan $\mathrm{H}_{0}$, oleh karena itu $\mathrm{H}_{0}$ diterima dan $\mathrm{H}_{\mathrm{a}}$ ditolak. Dapat disimpulkan bahwa lingkungan kerja nonfisik secara parsial mempunyai pengaruh yang positif terhadap kinerja pegawai. Sedangkan nilai $t_{3 \text {-hitung }}=-0,555<$ dari nilai $\mathrm{t}_{\text {-tabel }} 1,998$, dan $\mathrm{t}$-hitung berada pada daerah penolakan $\mathrm{H}_{0}$, oleh karena itu $\mathrm{H}_{0}$ diterima dan $\mathrm{H}_{\mathrm{a}}$ ditolak. Work interference with family secara parsial mempunyai pengaruh yang negatif terhadap kinerja pegawai.

\section{Pembahasan}

Berdasarkan hasil analisis, maka interprestasi temuan hasil penelitian pertama adalah sebagai berikut. Secara parsial hasil penelitian mendukung hipotesis pertama bahwa variabel komitmen kerja berpengaruh positif dan signifikan terhadap kinerja pegawai pada Badan Kepegawaian Dan Pengembangan Sumber Daya Manusia Kabupaten Gianyar. Hal ini ditunjukan dengan persamaan regresinya $Y=10,967+0,488(1)+0,166(0)+-0,050(0)$ dan bernilai positif. Nilai $t$-hitung 3,605 > dari nilai $t$-tabel 1,998 sehingga dapat disimpulkan bahwa komitmen kerja mempunyai pengaruh yang positif dan signifikan terhadap kinerja pegawai pada Badan Kepegawaian Dan Pengembangan Sumber Daya Manusia Kabupaten Gianyar.

Hal ini terjadi karena staf sudah banyak memiliki komitmen, seperti bertanggung jawab atas pekerjaannya seperti komitmen waktu, datang dan pulang kerja tepat waktu, sudah "memiliki" rasa pegawai terhadap organisasinya, sehingga pegawai bekerja dengan bertanggung jawab dan menyelesaikan pekerjaan yang diberikan oleh atasan. Komitmen karyawan adalah rasa identifikasi, keterlibatan dan loyalitas yang dinyatakan oleh seorang pegawai terhadap organisasinya (Darmawan \& Wibawa, 2019; Wolomasi et al., 2019). Semakin lama pegawai bekerja akan semakin berkomitmen untuk bekerja dan berdampak pada kinerja dibandingkan dengan pegawai yang belum lama bekerja. Bahkan ada pegawai yang merasa masalah kantor bukan masalahnya pribadi. Adanya pegawai bekerja di Badan Kepegawaian Dan Pengembangan Sumber Daya Manusia Kabupaten Gianyar bukan karena keinginannya tapi merupakan kebutuhan. Ada pegawai yang merasa tidak terlalu terikat secara emosional dengan kantornya, bahkan ada pegawai yang tidak mempunyai rasa "memiliki" yang kuat terhadap kantornya. Hasil penelitian ini konsisten dengan penelitian sebelumnya yang menyatakan bahwa komitmen berpengaruh positif dan signifikan terhadap kinerja pegawai (Lengkong, 2018; Lestri, 2020).

Temuan kedua, pengaruh lingkungan kerja nonfisik terhadap kinerja pegawai pada Badan Kepegawaian Dan Pengembangan Sumber Daya Manusia Kabupaten Gianyar. Secara parsial hasil penelitian mendukung hipotesis kedua bahwa variabel lingkungan kerja nonfisik berpengaruh positif terhadap kinerja pegawai pada Badan Kepegawaian Dan Pengembangan Sumber Daya Manusia Kabupaten Gianyar. Hal ini ditunjukan dengan persamaan regresinya $Y=10,967+0,488(0)+0,166$ (1) $+-0,050$ (0) dan bernilai positif. Nilai t-hitung $0,961<$ dari nilai $t$-tabel 1,998 sehingga dapat disimpulkan bahwa Lingkungan kerja nonfisik tidak ada pengaruh terhadap kinerja pegawai Ppda 
Badan Kepegawaian dan Pengembangan Sumber Daya Manusia Kabupaten Gianyar. Temuan ini diperkuat dengan penelitian sebelumnya yang menyatakan lingkungan kerja nonfisik tidak berpengaruh terhadap kinerja pegawai (Noorainy, 2017; Suryani, 2019).

Hal ini diketahui karena hubungan antara sesama rekan kerja, bawahan, dan atasan kurang baik. Hubungan baik perlu dilakukan karena saling membutuhkan dan hal tersebut menjadi peran paling penting. Hal tersebut sangat dibutuhkan karena hubungan kerja yang terbentuk sangat memengaruhi psikologis karyawan (Lestri, 2020; Nabawi, 2019). Suatu kondisi lingkungan dikatakan baik atau sesuai apabila manusia dapat melaksanakan kegiatannya secara optimal, sehat, aman, dan nyaman. Ketidaksesuaian lingkungan kerja dapat dilihat akibatnya dalam jangka waktu yang lama. Lebih jauh lagi, keadaan lingkungan yang kurang baik dapat menuntut tenaga dan waktu yang lebih banyak dan tidak mendukung diperolehnya rancangan sistem kerja yang efisien (Noorainy, 2017).

Temuan ketiga, Pengaruh work interference with family terhadap kinerja pegawai pada Badan Kepegawaian Dan Pengembangan Sumber Daya Manusia Kabupaten Gianyar. Secara parsial hasil penelitian mendukung hipotesis ketiga bahwa variabel work interference with family berpengaruh negatif terhadap kinerja pegawai pada Badan Kepegawaian Dan Pengembangan Sumber Daya Manusia Kabupaten Gianyar. Hal ini ditunjukan dengan persamaan regresinya $Y=$ $10,967+0,488(0)+0,166(0)+-0,050$ (1) dan bernilai negatif. nilai $t$-hitung $-0,555<$ dari nilai $t$-tabel 1,998, dan t-hitung sehingga dapat disimpulkan bahwa work interference with family secara parsial mempunyai pengaruh yang negatif dan signifikan terhadap kinerja pegawai. Temuan ini diperkual dengan temuan yang menyatakan work interference with family berpengaruh negatif signifikan terhadap kinerja (Hariyadi, 2018).

Bila seseorang mengalami konflik pekerjaan keluarga (work interference with family), maka pemenuhan salah satu peran antara pekerjaan atau keluarga akan terganggu sehingga akan berdampak terhadap kinerja. Work interference with family dapat menurunkan kinerja karyawan. Menurunya kinerja karyawan akan memberikan dampak terhadap pencapaian tujuan organisasi, meningkatnya absensi, serta dapat menurunnya komitmen organisasional. Work interference with family adalah sebuah konflik antar peran dimana tuntutan secara keseluruhan baik waktu maupun ketegangan yang disebabkan oleh pekerjaan menganggu untuk melakukan tanggung jawab yang berkaitan dengan keluarga. Adapun dalam penelitian ini work interference with family berpengaruh negatif terhadap kinerja pegawai (Annisa \& Amallia, 2021; Hariyadi, 2018; Hekayanti \& Yulianti, 2021).

Secara simultan hasil penelitian mendukung hipotesis keempat bahwa variabel komitmen kerja, lingkungan kerja nonfisik dan work interference with family berpengaruh positif terhadap kinerja pegawai pada Badan Kepegawaian dan Pengembangan Sumber Daya Manusia Kabupaten Gianyar. Hal ini ditunjukan dengan persamaan regresinya $Y=10,967+0,488 X_{1}+0,166 X_{2}+-0,050 X_{3}$ dan bernilai positif. Nilai $f_{\text {-hitung }} 5,682>$ dari nilai $f_{\text {-tabel }} 1,518$ dan $f_{\text {-hitung }}$ dengan nilai sigmifikansi 0,002 yang menunjukan bahwa variabel komitmen kerja, lingkungan kerja nonfisik dan workilnterference wth family berpengaruh positif dan signifikan terhadap kinerja pegawai pada Badan Kepegawaian Dan Pengembangan Sumber Daya Manusia Kabupaten Gianyar.

Berdasarkan pembahasan dapat dipahami bahwa komitmen kerja, lingkungan kerja non fisik dan work interference with family merupakan faktor penentu kinerja karyawan pada Badan Kepegawaian Dan Pengembangan Sumber Daya Manusia Kabupaten Gianyar. Temuan yang ada menunjukkan bahwa komitmen kerja, lingkungan kerja nonfisik dan work interference with family yang baik. Pemanfaaatan pembiayaan dengan indikator kesesuaian antara perencanaan dan pelaksanaan terlaksana dengan baik. Keterbatasan penelitian ini adalah pengamatan hanya dilakukan pada satu dinas pemerintah, sehingga hasil penelitian ini belum bisa digeneralisasikan pada pemerintahan lain. Di samping itu, dari segi jumlah sampel yang digunakan dalam penelitian ini masih sedikit, sehingga diharapkan bagi penelitian lain untuk menggunakan jumlah sampel penelitian yang lebih luas agar hasil penelitian lebih teruji kehandalannya. Kajian ini dapat dijadikan sebagai evaluasi dalam meningkatkan kinerja karyawan. 


\section{Simpulan}

Berdasarkan hasil penelitian data dan pembahasan, maka komitmen kerja, lingkungan kerja non fisik dan work interference with family secara simultan berpengaruh terhadap kinerja pegawai pada Badan Kepegawaian dan Pengembangan Sumber Daya Manusia Kabupaten Gianyar, berarti meningkatnya Komitmen Kerja, Lingkungan Kerja Non Fisik dan Work interference with family secara simultan berarti akan diikuti dengan meningkatkan kinerja pegawai secara nyata. Implikasi penelitian ini dapat memberikan evaluasi dalam meningkatkan kinerja karyawan.

\section{Daftar Pustaka}

Aini Kusniawati, N. (2019). Pengaruh Lingkungan Kerja dan Disiplin Kerja terhadap Kinerja Karyawan pada PT Gapuraning Rahayu Ciamis. Jurnal IImu Manajemen, 1(1), 49-70.

Annisa, N. N., \& Amallia, F. (2021). Peran Kepuasan Kerja Memediasi Work Family-Conflict dan Stres Kerja terhadap Kinerja Guru Wanita Sekolah Menengah Kejuruan ( SMK ) Magelang Saat PJJ (Pembelajaran Jarak Jauh ) Berlangsung. Jurnal Magisma, 9(2), 152-161.

Darmawan, I. G. W., \& Wibawa, I. M. A. (2019). Pengaruh Kompensasi Finansial, Lingkungan Kerja Non-Fisik, dan Komitmen Organisasional terhadap Semangat Kerja Karyawan. E-Jurnal Manajemen Universitas Udayana, 8(8), 5118-5138. https://doi.org/10.24843/ejmunud.2019.v08.i08.p15.

Effendi, M., \& Yogie, F. (2019). Pengaruh Motivasi dan Disiplin Kerja terhadap Kinerja Karyawan. Journal of Management and Bussines (JOMB), 1(1), 88-98. https://doi.org/10.31539/jomb.v1i1.654.

Farhah, A., Ahiri, J., \& Ilham, M. (2020). Pengaruh Motivasi Kerja Dan Disiplin Kerja Terhadap Kinerja Karyawan. Jurnal Online Program Studi Pendidikan Ekonomi, 5(1), 1. https://doi.org/10.36709/jopspe.v5i1.13326.

Filatrovi, E. W., Kurniawati, N. I., \& Setiyono, T. A. (2021). Mengelola Kinerja Karyawan Bank Syariah di Masa Pandemi Covid-19 Melalui Islamic Work Ethics. Jurnal Ilmiah Ekonomi Islam, 7(02), 1140-1146. https://doi.org/10.29040/jiei.v7i2.2744.

Hariyadi, M. K. (2018). Pengaruh Work Interfering With Family, Family Interfering With Work dan Orientasi Etika terhadap Turnover Intentions dengan Job Satisfaction sebagai Variabel Intervening (Studi Empiris pada Auditor Kap Jakarta Terdaftar Di Ojk). Menara IImu, 12(79), 166-173.

Hekayanti, K., \& Yulianti, P. (2021). Pengaruh Work Demand dan Work Home Interference Terhadap Burnout pada Perawat Wanita RS. Jasa Kartini. Jurnal IImiah MEA (Manajemen, Ekonomi, \& Akuntansi), 5(2), 1377-1397. https://doi.org/10.31955/mea.vol5.iss2.pp1377-1397.

Jufrizen, J. (2017). Efek Mediasi Kepuasan Kerja pada Pengaruh Kompensasi terhadap Kinerja Karyawan. Jurnal IImiah Manajemen Dan Bisnis, 17 (01), 34-53. https://doi.org/10.30596\%2Fjimb.v17i1.1209.

Lengkong, V. P. K. (2018). Pengaruh Komitmen Organisasi dan Budaya Organisasi terhadap Kinerja Pegawai Di Bkdpsda di Kabupaten Halmahera Utara. Jurnal EMBA: Jurnal Riset Ekonomi, Manajemen, Bisnis Dan Akuntansi, 6(4), 1968-1977. https://doi.org/10.35794/emba.v6i4.20918.

Lestri, L. (2020). Pengaruh Komitmen Kerja, Motivasi Kerja, Stres Kerja, Lingkungan Kerja Non Fisik, dan Disiplin Kerja terhadap Kinerja Guru SMA Kartika I-5 Padang. 2020. http://repo.stkippgri-sumbar.ac.id/id/eprint/11988/.

Mustopa, R. (2020). Pelatihan dan Pengembangan Manajemen Daya Manusia di Masa Pandemi $\begin{array}{lllll}\text { Covid-19. Jurnal Sosial Dan Teknologi } & \text { (SOSTECH), }\end{array}$ https://sostech.greenvest.co.id/index.php/sostech/article/view/21.

Nabawi, R. (2019). Pengaruh Lingkungan Kerja, Kepuasan Kerja dan Beban Kerja terhadap Kinerja Pegawai. Maneggio: Jurnal Ilmiah Magister Manajemen, 2(2), 170-183. https://doi.org/10.30596/maneggio.v2i2.3667. 
Noorainy, F. (2017). Pengaruh Lingkungan Kerja Fisik Dan Non-Fisik terhadap Kinerja Pegawai pada Sekretariat Daerah Kabupaten Pangandaran. Journal of Management Review, 1(2), 75. https://doi.org/10.25157/jmr.v1i2.701.

Rachmawati, R. W. (2017). Pengaruh Pelatihan dan Motivasi Kerja terhadap Kinerja Karyawan PT. Bank Bjb Kantor Cabang Suci Bandung. Jurnal Manajemen Dan Pemasaran Jasa, 9(1), 1. https://doi.org/10.25105/jmpj.v9i1.802.

Sugiono. (2018). Metode Penelitian Pendididkan Pendekatan Kuantitatif, Kualitatif, dan R\&D. Alfabeta.

Suryani, N. L. (2019). Pengaruh Lingkungan Kerja Non-Fisik dan Komunikasi terhadap Kinerja Karyawan pada PT Bangkit Maju Bersama Di Jakarta. JENIUS (Jurnal Ilmiah Manajemen Sumber Daya Manusia), 2(3), 419-435. https://doi.org/10.32493/jjsdm.v2i3.3017.

Wibowo, A. A. (2017). Komitmen dan Kompensasi terhadap Prestasi Kerja di PT Somit Karsa Trinergi Jakarta. Jurnal Ekonomi Dan Bisnis, 1(1), 1-19. https://doi.org/10.22236/agregat_vol1/is1pp1-19.

Wolomasi, A. K., Werang, B. R., \& Asmaningrum, H. P. (2019). Komitmen Kerja dan Pengaruhnya terhadap Semangat dan Kepuasan Kerja Guru Sekolah Dasar. Musamus Journal of Primary Education, 2(1), 13-23. https://doi.org/10.35724/musjpe.v2i1.1572. 